\title{
Institutionalization and Globalization in Arab Countries
}

\author{
Prof. Asim Alaraji \\ Dhofar University - Sultanate of Oman \\ dr_asim39@hotmail.com
}

\section{Doi:10.5901/mjss.2015.v6n4s3p617}

\begin{abstract}
The objective of this research is to determine whether there are paradoxes between institutionalization imperatives, on the one hand, and the contemporary modernization imperatives, on the other hand, in the context of developing countries. In addition, some suggestions for minimizing the possible negative effects of such paradoxes on developing countries are explored.. A random sample of two Arab countries is selected for the purpose of analysis. Literature review and data analysis revealed that there are real paradoxes between institutionalization and globalization in the context of the surveyed Arab countries. Findings from the analysis also indicated the possible negative effects of such paradoxes in the on-going institutionalization and in the implementation of the five-year developmental plans. Carrying out a follow-up system in parallel with planning steps to address incoming varying impulses of globalization on time and consequently maintain plans close to ongoing environmental changes is one possible suggestion regarding the probable effects of the paradoxes. A second suggestion is to adopt a planned and selective national policy that is open to the growing influence of incoming globalization imperatives. This approach would safeguard the cultural and social imperatives of local institutions while still benefiting from the latest scientific and technological advancement of more advanced countries. However, the balance between these two requirements may not always be an easy task because a number of developing countries lack some required technologies and expertise.
\end{abstract}

Keywords: paradox, institutionalization imperatives, contemporary modernization imperatives, globalization.

\section{Introduction}

Arab countries, as with other developing countries, are undergoing two different experiences: Institutionalization and Globalization. Institutionalization started almost four decades ago and is still ongoing in Arab countries, while globalization is a relatively contemporary event.

Institutionalization aims at building a systemized and stable structural and procedural state system. Despite some setbacks in Arab state administrative systems, it is still clear that there has been an overall trend towards institutional systemization and homogeneity throughout the last forty years.

Globalization, on the other hand, aims at maximizing interrelationships between developed and underdeveloped countries. This actually means maximizing economic, scientific, technological, social and cultural impulses from more advanced countries to Arab and other developing countries.

Each of these two experiences aims at building institutionalization on different sets of imperatives.

Local institutionalization relies on local, social and cultural imperatives. Globalization aims at remodeling local institutionalization to include some imperatives from more advanced countries together with existing local imperatives.

The objective of the present research is to determine whether there are actual contradictions between the two experiences in the context of the Arab countries.

Recommendations from this research are expected to play an important role in minimizing the possible negative effects resulting from the probable contradiction between institutionalization and globalization in Arab countries.

\section{Research Questions}

- Are there actual contradictions between institutionalization imperatives and contemporary globalization imperatives in the context of Arab states?

- Can such contradictions lead to administrative chaos and impede local five-year development plans in the context of Arab states?

- What are some suggestions to address the probable negative effects of the paradox whenever it appears? 


\section{Research Methodology}

This research project is aimed at performing a comparative analysis of globalization and institutionalization imperatives from the literature and in the five-year development plans of the countries concerned in order to reveal probable negative outcomes of contradictions. Probable suggestions can be developed accordingly. A random sample of two countries (Jordan and Egypt) out of all of the Arab countries is selected for the purpose of analysis.

\section{Analysis of Institutionalization Imperatives}

Scott $(1995,2004)$ has defined institutionalization as the process of crystallizing values, rules and behavioural patterns and consequently creating a level of systemization and stability within the concerned organization. Johnson and Rhodes (2007) provide a similar definition of institutionalization and emphasize that its goal is to create a state of stability, predictability, consistency and systemization in the concerned organization. In terms of the stages of institutionalization, Rostow (1960) stated that modernization, which implies institutionalization, goes through five stages starting with "primitive society" where institutionalization is almost nil. Then, it goes through what he calls the "take off" stage to the "modernization" stage in which institutionalization becomes mature. Riggs (2006) calls the first stage of modernization, which includes institutionalization, "fused society" where institutionalization is very weak. Then, the society goes through what he calls a "prismatic society" stage in which institutionalization is developing. Finally, in the "diffracted society" stage, institutionalization becomes mature. Indeed, Rostow's and Riggs' models need further field evidence. These authors also suffer from westernization biases when addressing non-western cultural systems.

Bjorck (2004) developed a rather empirical behavioural outlook of the stages of institutionalization development, illustrated as follows:

1. The starting stage is the adoption of some behavioural values and ethics.

2. When individuals actually behave in accordance with those values and ethics, institutionalization has appeared.

3. Whenever individuals adopt new, additional values and ethics and translate them into actual behavioral patterns, institutionalization is renewed and developed.

4. After a period of time, adopted values, ethics and related behavioral patterns become crystallized and stabilized. This means that institutionalization becomes well established.

5. In the last stage, individuals and organizational behavior will be judged in accordance to that well established institutionalization.

Indicators for measuring institutionalization

Huntington $(1965,1968)$ has stated four indicators for measuring levels of institutionalization in any organization: "Autonomy ", "Adaptability", "Complexity" and "Coherence".

Brunsson (1999) has noted two indicators: "Routinization" and "Standardization". Goetz and Peters (1999) have stated two indicators: "congruence" and "exclusivity".

In the context of five-year national developmental plans, which are the major formal tool for building institutionalization in Arab countries as well as likely other developing countries, the above-mentioned eight indicators can be understood as follows:

"Autonomy" refers to the level of plan independence in terms of its budget and other financial resources.

"Adaptability" means the level of a plan's responsiveness to environmental changes. Changes in the plan's implementation in response to public demands or state financial measures demonstrate "adaptability".

"Complexity" refers to the level of variation and the multiplicity of sub-goals and relationships inside the plan.

"Coherence" refers to the level of effectiveness and strength of functional relationships among various parts and stages of the plan.

"Routinization" means the level of recurrence and the sequence of the state's five-year developmental plans over a long period of time.

"Standardization" refers to levels of adopting statistical and digital language in formulating the goals and means of the five-year developmental plans.

"Congruence" means the level of harmony among the various components and stages of the plan.

"Exclusivity" refers to the level of uniqueness of the national five- year developmental plan in comparison with other plans inside the concerned state.

The more a plan works at materializing these eight indicators, the more it helps to create institutionalization in a society. This generally means that the level of institutionalization in a society is almost the levels of the incorporation of 
the eight indicators in its five-year developmental plan.

Therefore, the levels of institutionalization in the sampled Arab states can be measured by diagnosing the extent of incorporation of the eight indicators in their national five- year plans (Table 1).

Table 1: Measuring Institutionalization levels based on the five years Developmental Planning Imperatives in Some Arab Countries

\begin{tabular}{|c|c|c|c|c|c|c|c|c|c|c|}
\hline \multirow[b]{2}{*}{ 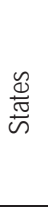 } & \multirow[b]{2}{*}{ 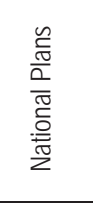 } & \multirow[b]{2}{*}{ 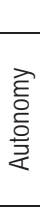 } & \multicolumn{8}{|c|}{ Planning Imperatives as expressed in the five year Plans } \\
\hline & & & $\begin{array}{l}\text { 訔 } \\
\frac{\pi}{0} \\
\frac{\pi}{0} \\
\frac{\pi}{4}\end{array}$ & $\frac{\widehat{\frac{\pi}{x}}}{\frac{0}{\overline{0}}}$ & 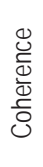 & 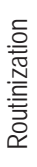 & 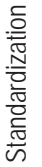 & 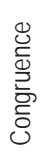 & 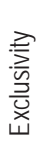 & $\frac{0}{\frac{n}{\pi}} \frac{0}{0}$ \\
\hline \multirow{11}{*}{ 恿 } & $1970-74$ & $\begin{array}{l}\text { W } \\
2\end{array}$ & $\begin{array}{l}\mathrm{M} \\
3\end{array}$ & $\begin{array}{c}M \\
3\end{array}$ & $\begin{array}{l}\text { W } \\
2\end{array}$ & $\begin{array}{c}\mathrm{H} \\
4\end{array}$ & $\begin{array}{l}\text { W } \\
2\end{array}$ & $\begin{array}{l}\text { W } \\
2\end{array}$ & $\begin{array}{c}\mathrm{H} \\
4\end{array}$ & 22 \\
\hline & 1975-79 & W & M & $M$ & W & $\mathrm{H}$ & W & $M$ & $\mathrm{H}$ & 23 \\
\hline & $1980-84$ & W & $\begin{array}{l}M \\
3\end{array}$ & $\mathrm{H}$ & $M$ & $\mathrm{H}$ & $M$ & $\mathrm{M}$ & $\mathrm{H}$ & 26 \\
\hline & $1985-89$ & $M$ & $M$ & $\mathrm{H}$ & $M$ & $\mathrm{H}$ & W & $M$ & $\mathrm{H}$ & 26 \\
\hline & & 3 & 3 & 4 & 3 & 4 & 2 & 3 & 4 & $\angle 0$ \\
\hline & 1990-94 & $\begin{array}{l}\mathrm{H} \\
4\end{array}$ & $\begin{array}{c}M \\
3\end{array}$ & $\begin{array}{c}\text { VH } \\
5\end{array}$ & $\begin{array}{c}M \\
3\end{array}$ & $\begin{array}{l}\mathrm{H} \\
4\end{array}$ & $\begin{array}{l}W \\
2\end{array}$ & $\begin{array}{l}M \\
3\end{array}$ & $\mathrm{H}$ & 28 \\
\hline & $1995-99$ & $\mathrm{H}$ & M & $\mathrm{VH}$ & M & $\mathrm{H}$ & $\mathrm{H}$ & M & $\mathrm{H}$ & 30 \\
\hline & $1950-99$ & 4 & 3 & 5 & 3 & 4 & 4 & 3 & 4 & 30 \\
\hline & 2000-04 & $\mathrm{H}$ & $\mathrm{H}$ & $\mathrm{VH}$ & M & $\mathrm{H}$ & $\mathrm{H}$ & M & $\mathrm{H}$ & 31 \\
\hline & & 4 & 4 & 5 & 3 & 4 & 4 & 3 & 4 & 31 \\
\hline & 2005-09 & $\mathrm{H}$ & $\mathrm{H}$ & $\mathrm{H}$ & M & $\mathrm{H}$ & $\mathrm{H}$ & M & $\mathrm{H}$ & 30 \\
\hline \multirow{14}{*}{$\begin{array}{l}\text { 듕 } \\
\text { 힘 }\end{array}$} & & W & W & $\mathrm{M}$ & W & $\mathrm{H}$ & W & W & $\mathrm{H}$ & \\
\hline & 1973-79 & 2 & 2 & 3 & 2 & 4 & 2 & 2 & 4 & 21 \\
\hline & $1976-80$ & W & W & $\begin{array}{l}M \\
\end{array}$ & W & $\mathrm{H}$ & W & W & $\mathrm{H}$ & 21 \\
\hline & & W & W & $\mathrm{M}$ & $M$ & $\mathrm{H}$ & $M$ & $M$ & $\mathrm{H}$ & 29 \\
\hline & 1981-85 & 2 & 2 & 3 & 3 & 4 & 3 & 3 & 4 & 24 \\
\hline & $1986-90$ & M & W & $\mathrm{H}$ & M & $\mathrm{H}$ & $\mathrm{H}$ & M & $\mathrm{H}$ & 27 \\
\hline & & $\mathrm{M}$ & $\frac{L}{M}$ & $\frac{4}{H}$ & $\frac{3}{M}$ & $\frac{4}{H}$ & 4 & 3 & $\frac{4}{H}$ & \\
\hline & 1991-95 & 3 & 3 & 4 & 3 & 4 & 3 & 3 & 4 & 27 \\
\hline & $06-2000$ & $\mathrm{H}$ & M & $\mathrm{VH}$ & $M$ & $\mathrm{H}$ & $\mathrm{H}$ & M & $\mathrm{H}$ & 30 \\
\hline & $96-2000$ & 4 & 3 & 5 & 3 & 4 & 4 & 3 & 4 & 30 \\
\hline & 2001-05 & H & M & $\mathrm{VH}$ & M & $\mathrm{H}$ & $\mathrm{VH}$ & M & $\mathrm{H}$ & 31 \\
\hline & & 4 & 3 & 5 & 3 & 4 & 5 & 3 & 4 & \\
\hline & 2006-10 & $\mathrm{H}$ & M & $\mathrm{VH}$ & M & $\mathrm{H}$ & VH & M & $\mathrm{H}$ & 31 \\
\hline & $2000-10$ & 4 & 3 & 5 & 3 & 4 & 5 & 3 & 4 & $\sigma_{1}$ \\
\hline
\end{tabular}

V.W. $=$ Very Weak $=1$

$W=$ Weak $=2$

$M=$ Middle $=3$

$\mathrm{H}=\mathrm{High}=4$

$\mathrm{VH}=$ Very High $=5$

It can be inferred from Table 1 that the levels of institutionalization, measured through the Likert five levels scale, had developed from 22 to 30 in Egypt and from 21 to 31 in Jordan. In other words, the accomplished levels of institutionalization in the sampled states have jumped over the median after almost four decades of developmental planning. 
Similarity among the surveyed states, in terms of their accomplished levels of institutionalization, can be attributed to the fact that both of Egypt and Jordan adopted incremental long term globalization policies and they both have similar social and cultural backgrounds. These factors most likely contributed to near identical interactions between local institutionalization imperatives and globalization imperatives and their respective outcomes in the surveyed states.

It is important to note that all of the incorporated indications of institutionalization in the five-year plans have not been incorporated in the Arab systems. Therefore, the above-mentioned levels of institutionalization, reflected in the fiveyear plans, are in fact much more than the actual levels in the field.

The relatively slow processes of institutionalization through the four decades of national developmental planning is not totally attributed to lack of planning experiences and to other local factors. The effects of globalization imperatives could probably be significant reasons for impeding the on-going processes of institutionalization.

\section{Analysis of Globalization Imperatives}

Bhagwati (2004) given almost the same meaning to globalization in that it aims to integrate a national economy in the world economy. Globalization also implies an exchange of sciences, technology and social and cultural values among nations.

Fuhr (2001) states that globalization refers to an exchange of sciences, technology, politics, social and cultural values among nations. This naturally implies that the movement of sciences, technology, social and cultural imperatives goes from more developed countries to less developed countries, including Arab countries (Cox, 1993; Wilson, 1993; Kelly, 2001; Queleh, 2002).

Although the effects of globalization on developing countries seem to be positive, as indicated in the abovementioned references, there are a number of authors who note certain negative effects. For exampleSmith (2006) and Lunt (2002) have stated that although globalization leads to cultural and educational exchange among developed and underdeveloped countries, at the same time, it also leads to conflicts among civilizations.

For the purpose of diagnosing the possible negative effects of globalization on institutionalization, the following globalization indicators are derived from the above definitions:

1. Technological impulses coming from more advanced to less advanced countries.

2. Scientific impulses coming from more advanced to less advanced countries.

3. Economic impulses coming from more advanced to less advanced countries.

4. Social and cultural impulses coming from more advanced to less advanced countries.

Based on the above mentioned points, the effects of globalization imperatives can be clarified as in Figure 1.

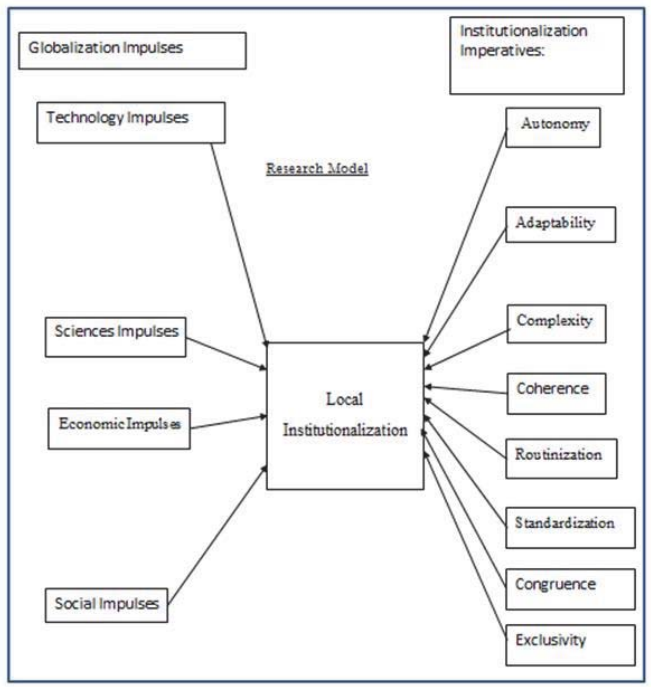

Figure 1: Globalization imperatives and institutionalization imperatives. 
When contrasting globalization imperatives with institutionalization imperatives as indicated in Figure 1, a number of points can be concluded:

1. The maximization of incoming globalization imperatives in the Arab country could lead to the weakening of local institutionalization imperatives such as congruency, exclusivity and coherence.

2. The maximization of incoming globalization imperatives could exceed the absorptive capacity of the local developmental plan. A consequential number of incoming variables of globalization will stay functioning out of local institutionalization. This phenomenon, in turn, means weakening both local planning and local institutionalization.

3. An increasing irregularity of incoming globalization imperatives could make additional local institutionalization imperatives, such as adoptability and complexity, inadequate. This in turn leads to weakening local plans and institutionalization. In other words, all of the above mentioned possibilities could ultimately lead to administrative chaos (Kiel, 1994; Farazmand, 2003) and planning failure.

4. In addition to the above points, the expected interaction between incoming globalization impulses and local institutionalization variables could drastically change the local environment and consequentially make the national developmental plan an isolated entity in the new environment. This means a planning setback. Waterston (1988) indicates that planning failures in developing countries are predominant without excluding Arab States. Moreover, the U.N. Statistical Books (1990-2010) present a number of indicators regarding planning setbacks in various developing countries.

\section{Conclusion and Recommendations}

It can be concluded from the analysis herein that actual paradoxes indeed exist between globalization imperatives and local institutionalization imperatives in the state sample as indicated in Figure 1. This phenomenon could usually lead to slowing down institutionalization, as indicated in Table 1, and to limiting the success of plan implementation, as Waterson (1988) stated and as indicated in the U.N. Statistical Year Books (1990 - 2010).

Naturally increasing weaknesses of institutionalization and planning implementation could probably lead to chaos in the state.

Different suggestions have been developed to address cases of institutionalization failure and chaos (Shelton and Darling, 2003; Shelton et al., 2005).

In terms of setbacks in the implementation of national developmental plans, May (2010), David (2006), and Lloyd (1978) have suggested performing periodic reviews of the different stages of planning processes. They suggest doing this up to the end of the implementation stage, in order to address the impact of globalization impulses and any unexpected changes they may cause.

Nguyen and Mintzberg (2003) have suggested the adoption of contingency planning in addition to the main national developmental plan for the same purpose.

McConkey (1988), Linnemen and Chandran (1981) and Roney (2003) have recommended that contingency plans be developed and adopted by operational levels in an organization. In doing so, the impact of direct and close contact with globalization impulses as well as other unexpected changes can be institutionally managed.

Lloyd (1978) has suggested a similar model that she calls "Don't Define the Problem" for the same purpose.

With regard to Arab countries, a selective planned state policy can be adopted to address irregular globalization impulses. An open door policy regarding incoming scientific and technological globalization impulses is always preferable.

A selective and closely guarded state policy to address social and cultural impulses of globalization to minimize their possible negative effects on local institutionalization processes is highly needed.

There is no doubt that the lack of required planning expertise and technical knowledge, despite limited and formal state backing, in a developing country may limit the expected positive outcomes of the above-mentioned suggestions.

\section{References}

Bhagwati, J. (2004), In Defense of Globalization, Oxford University Press, Oxford, UK.

Bjorck, F. (2004), "Institutional theory: a new perspective for research into IS/IT security in organizations", paper presented at Proceedings of the $37^{\text {th }}$ Annual Hawaii International Conference on System Sciences (HICSS), 5-8 January.

Brunsson, N. (1999) 'Standardization as Organization', in M. Egeberg and P. Laegreid )eds) Organizing Political Institutions. Essays for Johan P. Olsen, pp. 109-28 Oslo: Scandinavian University Press.

Cox, R.W. (1993), "Structural issues of global governance", in Gill, S. (Ed.), Gramsci, Historical Materials and International Relations, 
Cambridge University Press, Cambridge, pp. 259-289.

David, F.R. (2006), Strategic Management: Concepts and Cases, Prentice Hall of India, New Delhi.

Farazmand, A. (2003), "Chaos and transformation theories: a theoretical analysis with implications for organization theory and public management", Public Organization Review, Vol. 3, No. 3, pp. 127-139.

Fuhr, H. (2001), "Constructive pressures and incentive to reform: globalization and its impact on public sector performance and governance in developing countries", Public Management Review, Vol. 3, No. 3, pp. 43-59.

Goetz, K.H. and Peters, B.G. (1999), "Institutional theory and political executives: creating executive organizations: east and west", paper presented at Conference on Institutional Theory, 18-19 October, Ross Priory, Dunb., Scotland.

Huntington, S.P. (1965), "Political development and political decay", World Politics, Vol. 17, No. 3, pp. 163-178.

Huntington, S.P. (1968), Political Order in Changing Societies, Yale University Press, New Haven, CT.

Johnson, M.M.N. and Rhodes, R. (2007), "Institutionalization: a theory of human behavior and social environment", Advances in Social Work, Vol. 18, No. 1, pp. 19-28.

Kelly, J. (2001), "Globalization is not inevitable", World Trade, Vol. 14, No. 7, pp. 65-78.

Kiel, D.L. (1994), Managing Chaos and Complexity in Government: A New Paradigm of Managing Change, Innovation, and Organizational Renewal, Jossey-Bass, San Fransisco, CA.

Linneman, R. and Chandran, R. (1981), "Contingency planning: a key to swift managerial action in the uncertain tomorrow", Managerial Planning, Vol. 29, No. 4, pp. 74-91.

Lloyd, I. (1978), "Don't define the problem", Public Administration Review, Vol. 38, No. 3, pp. 283-286.

Lunt, P. (2002), "The dos \& don'ts of globalization", Transform Magazine, Vol. 11, No. 6, pp.17-23.

May, G. (2010), Strategic Planning: Parameters for Small Business, Business Press..

McConkey, D. (1988), "Planning in a changing environment", Business Horizons, Vol. 31, No. 5, pp. 64-72.

Nguyen, M. and Mintzberg, L.M. (2003), "The rhythm of change", MIT Sloan Management Review, Vol. 44, No. 4, pp. 79-84.

Queleh, J.A. (2002), "Does globalization have staying power", Marketing Management, Vol. 11, No. 2, pp. 18-23.

Riggs, F.W (2006), "The prismatic model: conceptualizing transitional societies", in Otenyo, E. and Lind, N. (Eds.), Comparative Public Administration: Essential Readings, Elsevier, New York, NY, pp. 52-56.

Roney, C.W. (2003), "Planning for strategic contingencies", Business Horizons, Vol. 46, No. 2, pp. 35-42.

Rostow, W. (1960), The Stages of Economic Growth: A Non-Communist Manifesto, Cambridge University Press, Cambridge, UK.

Scott, W.R. (1995), Institutions and Organizations, Sage, Thousand Oaks, CA.

Scott, W.R. (2004), "Institutional theory", in Ritzer, G. (Ed.), Encyclopedia Of Social Theory, Sage, Thousand Oaks, CA, pp. 408-414.

Shelton, C.D. and Darling, J.R. (2003), "From chaos to order: exploring new frountirs in conflict management", paper presented at the Midwest Academy of Management Conference, 4 April, Kansas City, MO.

Shelton, C., Yang, J. and Lie, Q. (2005), "Managing in an age of complexity: quantum skills for the new millennium", International Journal of Human Resources Development and Management, Vol. 5, No. 2, pp. 127-141.

Smith, D. (2006), Globalization: The Hidden Agenda, Polity Press, Cambridge, UK.

United Nations Secretariat (1990-2010), Statistical Year Books, United Nations, New York, NY.

Waterston, A.A. (1988), Planning: Lessons of Experience, John Hopkins University Press, Baltimore, MD.

Wilson, D. (1993), "Bureaucracy in international organizations: building capacity and credibility in a newly independent world", in Farazmand, A. (Ed.), Handbook of Bureaucracy, Marcel Dukker, New York. NY, pp. 305-318. 